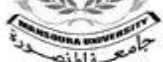

Mansoura University

Faculty of Tourism and Hotels

\title{
E-MARKEtING AS A COMPETITIVE AdVANTAGE IN TOURISTIC RESORTS
}

Extract of Master Thesis

\section{By}

Eman Mohamed El sayed Sheashaa

Master Researcher

Faculty of Tourism and Hotels - Mansoura University

Dr/Sherif Gamal Saad

Prof/Mahmoud Mahmoud

Alseagay

Ass. Prof of Hotel management-

Prof of Accounting Department -

Faculty of Tourism and Hotels Mansoura University

Faculty of Commerce - Mansoura University 
= E-Marketing as a Competitive Advantage in Touristic Resorts 


\section{E-MARKETING AS A COMPETITIVE ADVANTAGE IN TOURISTIC RESORTS}

Eman Mohamed El sayed Sheashaa ${ }^{1}$

\section{Abstract}

Dr/Sherif Gamal Saad $^{2}$
Prof/Mahmoud Mahmoud Alseagay $^{3}$

The main objective of this study is to recognize the Emarketing and its impact on enhancing the competitive advantage in five star resorts in Sharm El Sheikh City. Hence the importance of this research stems from the resorts need of a competitive advantage to strengthen its competitive status. So, the resorts management must give the competitive advantage a distinctive attention particularly in terms of resort services. This research will help resorts to access to the means that able them to create competitive advantages and determine strength and weakness points, and then broaden its market share and lead to the internationalization of these Resort. A questionnaire form was developed to collect the required data for this study. A total of 480 forms were randomly distributed to a sample of resort guests; only 421 forms (87.7\%) were valid for analysis. The majority of the surveyed guests showed interest in designs guestrooms and various means of comfort provided by resorts; they prefer resorts that offer fair prices and ensure quality standard of service. In general, they use travel agents and the internet for searching and booking the Resort. Therefore, the marketing managers of the five-star resorts should be interested in improving and developing E-marketing methods to achieve the aspirations of customers and achieve their satisfaction and help the resorts to increase their market share and enhance their competitiveness locally and globally.

Key words: E-Marketing, Competitive Advantage, Resorts 
= E-Marketing as a Competitive Advantage in Touristic Resorts

\section{التسويق الإلكتروني كميزة تنافسية في المنتجعات السياحية}

الهدف الرئيسي من هذه الدراسة هو التعرف على التسويق الإلكتروني وأثره ٍِِ

تعزيز الميزة التنافسية يِّ منتجعات الخمسة نجوم بمدينة شرم الشيخ. ومن هنا تنبع أهمية هذا البحث من حاجة المنتجعات إلى ميزة تنافسية لتعزيز مركزها التنافسي. لذا ، يجب على إدارة المنتجعات إعطاء الميزة التنافسية إهتماما مميزا خاصة فيما يتعلق بخدمات المنتجعات. سيساعد هذا البحث المنتجعات على الوصول إلى الوسائل التي تمكنها من خلق مزايا تنافسية وتحديد نقاط القوة والضعف ، ومن ثم توسيع حصتها ِِّ السوق وتؤدي إلى تدويل هذه المنتجعات. تم تطوير استمارة استبيان لجمـع البيانات المطلوبة لهذه الدراسة. تم توزيع •^؛ نموذج بشكل عشوائي على عينة من

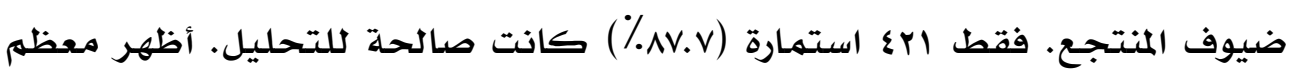
الضيوف الذين شملهم الاستطلاع اهتمامهم بتصاميم الغرف ووسائل الراحة المختلفة التي تقدمها المنتجعات ؛ أنهم يفضلون المنتجعات التي تقدم أسعارًا عادلة وتضمن مستوى جودة الخدمة. بشكل عام ، يستخدمون وكاء السفر والإنترنت للبحث عن وحجز المنتجع. ولذا فلابد من إهتمام مديري التسويق بالمنتجعات الخمس نجوم بتحسين وتطوير طرق وأساليب التسويق الإلكتروني ومراعاة التطورات التكنولوجية ومواكبة العصر ِِّ حملاتهم الدعائية لتحقيق تطلعات العملاء وتحقيق رضاهم ومساعدة المنتجعات بِّ زيادة حصتها السوقية و تعزيزقدراتها التنافسية محليًاً وعالمياً. الكلمات الدالة: التسويق الإدكتروني ، الميزة التنافسية ،المنتجعات السياحية 


\section{Introduction}

Marketing is all around you. For many years you have been a consumer and you have made decisions about products and services you liked and disliked. Marketing is the process of planning, pricing, promoting, selling, and distributing goods, ideas or services to make exchanges that satisfy guests (Simon Hudson, 2008). The Internet facilitates marketing processes by communicating with anybody at any time and in any place. It provides customers an access round the clock, cutting down all geographic borders, and enabling direct communication with customers (Corley et al., 2013). The major idea of marketing is to match the resort's capabilities with the needs of guests to realize the objectives of both sides. Then the resort has to improve strengths, either from the nature of the services it offers or from the way it uses these services, in order to provide guest satisfaction.

The E-marketing has a lot of benefits as, segmenting markets, building relationship markets, and offering several functions that traditional promotional media cannot such as reaching consumers around the world interactively at a lower cost. E-marketing practices for the hospitality industry include the use of a hotel's or resort's website together with online promotional techniques, like search engine marketing, interactive advertising, e-mail marketing and copartner ship conventions with other websites (Chaffey et al., 2006).

The E- marketing offers various online advertising tools contain e-mail advertising, Electronic Word of Mouth (E-WOM) advertising, affiliate advertising, banner advertising and search engine advertising. (Duffy and Dennis, 2005) mentioned that Email advertising is used to increase sales, attract new customers, inform existing customers on promotions and sales, and to develop a stable dialogue and relationship with guests. E- 
marketing enables resorts to improve their flexibility, interactivity, efficiency and competitiveness.

\section{Review of Literature}

There is no single definition of the concept of e-marketing. Some marketers confirm the function of the internet in the implementation of e-marketing, while others realize that term broadly. "E-Marketing is the use of electronic data and applications for planning and executing the conception, distribution and pricing of ideas, goods and services to create exchanges that satisfy individual and organizational goals and objectives" (Strauss and Frost, 2001).

According to The World Tourism Institution (2008) "The purpose of e-marketing is to exploit the Internet and other forms of electronic communication to communicate with target markets in the most cost-effective ways, and to enable joint working with partner organizations with which there is a common interest."

E-Marketing is the fastest, cheapest, most efficient and interactive marketing tool, (Abu El Naga, 2012*) has defined emarketing as the process of optimizing the use and effective development of digital marketing resources represented by the databases and the available experiences, knowledge and available information, individuals and public relations, as well as all facilities available on the Internet in order to support and achieve a competitive advantage in the e-business market.

(Sabra, 2009*), (Abdel Azim, 2008*) and (Bakri, 2007*) agreed that that the value that E-marketing achieves for both institutions and customers in the changing business environment is as follows :

-Access to global markets.

-Providing goods and services according to the needs and desires of customers.

- Get feedback for product development.

- Reduce costs and use flexible pricing. 
-Development of several new distribution channels.

-Use an interactive promotional method with customers.

-Support and activate customer relationship management.

- Achieve competitive advantage at the regional and global level.

To gain competitive advantage, it is important nowadays for a resort to have its own website, promote its own products and services through social networks and mobile applications, use email as a channel of communication with its guests, and apply all available Information-Communication Technology (ICT). Marketers should provide all information for potential guests in one place at any time of day, from anywhere in the world. (Dina Lončarić1 and Nensi Radetić, 2015). It is highly difficult to persist a competitive advantage in the hospitality industry. So to build a permanent competitive advantage, the successful resorts must pay precise attention to improve and apply their resources and abilities (Enz, 2008), because the effective management of resources and abilities allows a resort to outperform its competitors. In resort procedures, the implementation of innovative product or service concepts creates many unparalleled characteristics (Frehse, 2015). So achieving a competitive advantage is considered as the most important goal of a resort vision, because without achieving a competitive advantage, resort will have a few economic causes for existing (Kim\&Oh, 2004).

So to be competitive in the hospitality industry, attract more guests and achieve a high level of customer satisfaction, resorts need to apply the methods and techniques of e-marketing .

The following study is E-Marketing as a Competitive Advantage in the Touristic Resorts. It had covered the most EMarketing activities which take place in five-star Resorts in Sharm El Sheikh City. The researcher took 15 five-star Resorts in Sharm El Sheikh as a sample of the study.

\section{Problem of the study}


The revolution of information and communication technology and economic liberalization, which organized the world, led to strengthen competition and created a reality that is imperative to society study of the use of E-marketing techniques and competition literature to provide innovative and convenient services to the guests and achieve a sustainable competitive advantage for the resorts.

Vollmer and Precourt (2008) mentioned that the increasing of online communication channels results in both opportunities and challenges for marketers to measure the effectiveness of marketing and advertising.

\section{Research Questions}

1. To what extent are the five star resorts interested to apply Emarketing through its marketing plan?

2. What are the competitive advantages of resorts from the emarketing application?

3. What are the obstacles facing the application of E-marketing in the resorts?

4. What are the views and trends of the guests in the Resorts towards E-marketing mechanisms as a new trend in the hospitality industry?

\section{Aim and objectives of the Study}

The main aim of this research is to study e-marketing and its impact in reinforcing the competitive advantage in the resorts. The main aim may be achieved through the following objectives:

1. Highlight the E-marketing techniques, tools and channels used by Resorts in Sharm El Sheikh.

2. Recognize the advantages and disadvantages of applying the E-marketing techniques to the Resorts.

3. Identify which booking type that guests use and trust in searching for Resorts.

4. Identify the concept of a competitive advantage to reach the global market. 
5. Providing the proposed plan on how to use E-marketing in hospitality industry.

\section{Important of the study}

The importance of this research comes from the resorts need of a competitive advantage to strengthen its competitive status and realize its impact in achieving customer loyalty, granting competitive advantages and increasing the market share. So, the resorts management must give the competitive advantage a special interest especially in terms of resort services. This research will help resorts to identify to the means that able them to create competitive advantages and define strength and weakness points, and therefore broaden its market share and lead to the internationalization of the Resort.

\section{Research Limitations}

The research limitations were as follow:

(1) Place limitations:

The survey was limited to the working five star Resorts in Sharm El Sheikh City.

(2) Time limitations:

The survey was conducted over a period of six months, which permitted foreign and Egyptian guests who were in the Resorts between October 2017 and March 2018 to be surveyed.

\section{Research Methodology}

In order to identify the factors that have E-Marketing as a Competitive Advantage in Resorts from fifteen five star resorts in Sharm El Sheikh City were surveyed. The data collection process was conducted over a six months period during the moderately high summer season from October 2017 to March 2018. A total of 480 questionnaire forms were randomly distributed to guests; only 421 forms (87.7\%) were valid for analysis. The guests' questionnaire consisted of four sections. The first part collects the demographic data of the respondents. The second part intended to clarify the resort selection. The third part illustrates 
= E-Marketing as a Competitive Advantage in Touristic Resorts

the internet and E-marketing from the guest perspective. The fourth part clarifies the Social Media Networks.

The respondents were asked to determine their levels of agreement with each statement using a five-point Likert- scale (Strongly agree $=5$, agree $=4$, neutral $=3$, disagree $=2$ and strongly disagree $=1$ ). The Statistical Package for the Social Sciences (SPSS) version 22 was used to analyze and compute the collected data.

\section{Results and Discussion}

Validity and Reliability of the Managers Questionnaire Form

\begin{tabular}{|c|c|c|c|c|c|}
\hline Answers & $\begin{array}{c}\text { Distributed } \\
\text { Forms }\end{array}$ & $\begin{array}{c}\text { Lost } \\
\text { Forms }\end{array}$ & $\begin{array}{c}\text { Returned } \\
\text { Forms }\end{array}$ & $\begin{array}{c}\text { Excluded } \\
\text { Forms }\end{array}$ & $\begin{array}{c}\text { Valid } \\
\text { Forms }\end{array}$ \\
\hline Freq. & 60 & 11 & 49 & 7 & 42 \\
\hline \% & $100 \%$ & $18.3 \%$ & $81.7 \%$ & $11.7 \%$ & $70 \%$ \\
\hline
\end{tabular}

\section{Guests' Questionnaire Analysis}

Table No. (1)Demographic Data for the Guests

\begin{tabular}{|c|c|c|c|}
\hline \multirow{2}{*}{ Demographic Data } & \multirow{2}{*}{ Attribute } & \multicolumn{2}{|c|}{ Statistics } \\
\hline & & Freq & $\%$ \\
\hline \multirow{4}{*}{ Age } & From $20-30$ years & 68 & 16.2 \\
\hline & More than $30-40$ years & 158 & 37.5 \\
\hline & More than $40-50$ years & 140 & 33.3 \\
\hline & More than 50 years & 55 & 13.1 \\
\hline \multicolumn{2}{|l|}{ Total } & 421 & $100 \%$ \\
\hline \multirow{2}{*}{ Gender } & Male & 227 & 53.9 \\
\hline & Female & 194 & 46.1 \\
\hline \multicolumn{2}{|l|}{ Total } & 421 & $100 \%$ \\
\hline \multirow[b]{2}{*}{ Nationality } & Egyptian & 124 & 29.5 \\
\hline & Foreign & 297 & 70.5 \\
\hline \multicolumn{2}{|l|}{ Total } & 421 & $100 \%$ \\
\hline \multirow{3}{*}{ Education Level } & University Degree & 329 & 78.1 \\
\hline & Average Education & 1 & 0.2 \\
\hline & Post Graduate Degree & 89 & 21.1 \\
\hline
\end{tabular}




\begin{tabular}{|c|c|c|c|}
\hline & ننادق & & \\
\hline & Others & 2 & 0.5 \\
\hline Tota & & 421 & $100 \%$ \\
\hline
\end{tabular}

Table (1) shows the demographic profile of the respondents. As it can be observed from table (1), the average ages of the guests that their ages range from 20 - 30 years represents $16.2 \%$, the ages from $30-40$ years represent $37.5 \%$, the ages from $40-50$ years represent $33.3 \%$ and the ages above 50 years represent $13.1 \%$.The majority of the sample is "male" represent $53.9 \%$, while the numbers of female guests represent $46.1 \%$.The numbers of Egyptian guests represent 29.5\%, while the numbers of foreign guests represent $70.5 \%$.Their educational level was university Degree $78.1 \%, 0.7 \%$ had average education and $21.1 \%$ had Post Graduate Degree.

Table 2: Mean and Standard Deviations of Guests' Opinions.

\begin{tabular}{|l|l|c|c|}
\hline \multicolumn{2}{|c|}{ The Main Reasons for Resort Selection } \\
\hline 1 & $\begin{array}{l}\text { This Resort offers its facilities and } \\
\text { services with fair price. }\end{array}$ & 3.68 & 0.92 \\
\hline 2 & $\begin{array}{l}\text { This Resort has a good reputation and } \\
\text { brand name. }\end{array}$ & 3.91 & 1.00 \\
\hline 3 & $\begin{array}{l}\text { Security and safety are elements that affect } \\
\text { your selection for this Resort. }\end{array}$ & 4.19 & 0.77 \\
\hline & $\begin{array}{l}\text { Designs guestrooms and various means of } \\
\text { comfort have a great importance to you } \\
\text { (such as the general atmosphere of the } \\
\text { room, relaxation, tranquillity and easy } \\
\text { access to the room). }\end{array}$ & 0.65 \\
\hline 5 & $\begin{array}{l}\text { The diversity of entertainment services in } \\
\text { this resort. }\end{array}$ & 4.13 & 1.01 \\
\hline 6 & $\begin{array}{l}\text { Quality standard of services attracts you for } \\
\text { this Resort. }\end{array}$ & 4.24 & 0.79 \\
\hline \multicolumn{3}{|c|}{ The Internet and E-marketing } \\
\hline
\end{tabular}




E-Marketing as a Competitive Advantage in Tourstic Resorts
\begin{tabular}{|l|l|l|l|}
\hline 7 & $\begin{array}{l}\text { The Resort's website is easy to navigate, } \\
\text { simple and easy to understand. }\end{array}$ & 3.99 & 1.12 \\
\hline 8 & Awareness of internet advertisements. & 4.10 & 0.90 \\
\hline 9 & $\begin{array}{l}\text { It is important for me to know about the } \\
\text { reviews before reserving a resort. }\end{array}$ & 3.66 & 1.01 \\
\hline 10 & $\begin{array}{l}\text { Negative comments about resorts } \\
\text { affected me more than positive } \\
\text { comments. }\end{array}$ & 4.12 & 0.78 \\
\hline 11 & $\begin{array}{l}\text { Resort promotion through e-mail } \\
\text { impacts my purchase decision and my } \\
\text { satisfaction. }\end{array}$ & 3.51 & 1.07 \\
\hline 12 & $\begin{array}{l}\text { I am more convinced to purchase } \\
\text { services from experiences through } \\
\text { WOM. }\end{array}$ & 4.20 & 0.72 \\
\hline 13 & $\begin{array}{l}\text { I have actually reserved a resort after } \\
\text { getting more information about it from } \\
\text { the internet. }\end{array}$ & 4.32 & 0.85 \\
\hline 14 & $\begin{array}{l}\text { Online advertisement is very informative } \\
\text { and influences my decision. }\end{array}$ & 4.24 & 0.78 \\
\hline & \multicolumn{3}{|c|}{ Social Media Networks } \\
\hline 15 & $\begin{array}{l}\text { Using social media sites is a fast and } \\
\text { efficient way to get more information. }\end{array}$ & 4.30 & 0.71 \\
\hline 16 & $\begin{array}{l}\text { I like to stay in touch with my friends on } \\
\text { social network sites like Facebook, } \\
\text { twitter etc. }\end{array}$ & 4.30 & 0.71 \\
\hline 17 & $\begin{array}{l}\text { I am aware of advertising messages on } \\
\text { the social media sites. }\end{array}$ & 3.94 & 0.87 \\
\hline 18 & $\begin{array}{l}\text { I usually pay attention to the paid } \\
\text { advertisements which appear on the } \\
\text { social media websites. }\end{array}$ & 3.37 & 0.98 \\
\hline 19 & $\begin{array}{l}\text { I use social media before a trip to get } \\
\text { information about destination, Resorts }\end{array}$ & 4.16 & 0.88 \\
\hline
\end{tabular}




\begin{tabular}{|c|c|c|c|}
\hline & nle's oninion & & \\
\hline 20 & $\begin{array}{l}\text { I use social media networks during or } \\
\text { after the trip to share information, } \\
\text { pictures or opinion about the trip with } \\
\text { friends. }\end{array}$ & 4.32 & 0.74 \\
\hline
\end{tabular}

Table (2) shows the results obtained from the questionnaire distributed to guests in five star Resorts in Sharm El Sheikh, the analysis shows the statements along with the mean and standard divisions.

\section{(1) The Main Reasons for Resort Selection}

The results showed that most respondents are searching for resorts that have fair prices. We deduce from that the fair price helps to increase sales in a competitive market and so, increase profits. The results show that the majority of customers are looking for a brand name because previous experience in these resorts or the experiences of their friends and relatives. Excellent branding gives a resort several advantages including establishing a positive reputation and building a unique image attractive to guests. The reputation of the resort is very important in attracting guests. The results showed that the security and safety factor is very important in influencing the purchasing decisions of guests. Most resorts contract with private security companies or have an independent security department because security and safety are important elements that guests take into account before booking a resort. The results indicated that the designs of guestrooms and various means of comfort have a great importance to the guests (such as the general atmosphere of the room, relaxation, tranquility and easy access to the room).These findings agreed with (Baruca P., 2012) who stated that, guests' resort choice is influenced by several factors like resort product, received information, and personal preferences. Important elements which create the competitive advantage of the resort are: product, location, product offers and services, quality, price and 
reputation. The perception of the investigated respondents agreed that "Quality standard of services attracts you for this Resort" with mean 4.24. Many benefits can be achieved by service quality such as establishing guest satisfaction, establishing guest loyalty, and providing a competitive advantage to a resort. The survey results showed that most respondents are searching for resorts that have fair prices. We deduce from that the fair price helps to increase sales in a competitive market and so, increase profits. The results show that the majority of customers are looking for a brand name because previous experience in these resorts or the experiences of their friends and relatives. Excellent branding gives a resort several advantages including establishing a positive reputation and building a unique image attractive to guests. The reputation of the resort is very important in attracting guests. The results showed that the security and safety factor is very important in influencing the purchasing decisions of guests. Most resorts contract with private security companies or have an independent security department because security and safety are important elements that guests take into account before booking a resort.

\section{(2) The Internet and E-marketing}

The results showed that the Resort's website is in general easy to navigate, simple and easy to understand. This result is consistent with (Yannopoulos P., 2011) who designed websites that concentrate on keeping customers informed and providing simple ways for customers to express their opinions, thoughts, and give questions to customer service and sales team. The results also show that the guests are aware of the internet advertisement. This is consistent with (Kotler et al., 2005) who indicated that, Advertising persuades people to buy a certain product or service. It fetches goods or services to the attention of consumers. The results showed that it is important for the guests to know about the experiences of the others before reserving a 
resort. (Lim, 2010) mentioned that 57\% of guests will search for online reviews before making a purchase of a product or service. The results show that negative comments about resorts affected the guests more than positive comments. This is consistent with (Goldsmith et al. 2008) who mentioned that, E-WOM, affects several cases such as awareness, anticipations and perceptions of the online users. In the hospitality industry, positive online reviews have an enormous role, which can increase the number of bookings in a hotel or a resort. The results showed that resort promotion through e-mail impacts guests' purchase decision and their satisfaction. The result comply with (Chaffey et al., 2008)who saw that, by using e-mail addresses, social network sites the hotel or the resort can establish a two-way communication method with guests and facilitate accessibility. The answers indicated that guests were more persuaded to purchase services when the messages were passed by people they know. This result is consistent with (Goyetteet al., 2010; Chaves et al., 2012) who mentioned that, E-WOM offers extremely major range of potential receptors, can influence the buying decisions and the consumers perceptions of quality, when a user performs a review of a product or service. The results also show that some guests have actually reserved a resort after getting more information about it from the internet. This result came into agreement with (Kotler, P. and Keller, K., 2009) who mentioned that E-marketing makes the consumers able to purchase service or products at any time only by simple click from their homes. Through the internet, customer can find help all the day, search for particular interactions over the internet. The results also show that online advertisement is very informative and influences the purchasing decision for the guests and this comes into agreement with (Hoy and Milne, 2010) who mentioned that, online advertising consider a form of online marketing based on the internet to attract guests by delivering 
messages through websites or advertising banners on other popular websites which leads online guests to the resort site.

\section{(3) Social Media Networks}

The results showed that most respondents are using social media sites because it is a fast and efficient way to get more information. The results consistent with (Ryan et al., 2012) who mentioned that, Online social networks are used to filter, discuss, disseminate, and confirm news, booking a hotel or a resort, and buying products. The results show that most respondents like to stay in touch with their friends on social network sites like Facebook, twitter etc. The internet world stats (2015) usage and population statistics mention that, the number of European Facebook users as of November 2015, are 309,576,660 users representing $51 \%$ from the European internet users and $37.6 \%$ from the Europa Population. The results showed that most guests are aware of advertising messages on the social media sites. The results indicated that many guests usually pay attention to the paid advertisements which appear on the social media websites. This finding agrees with (Wright, 2010; Bernoff, 2009) who pointed that social media became one of the cheapest tools of marketing and advertising as it can promote products and services to targeted markets at a low cost. Also, it is suitable for small operations that do not have enough money for promote their products/services (Tariq and Wahid, 2011). The social media advs are delivered not only from business to consumer $\mathrm{B} 2 \mathrm{C}$, but also from consumer to consumer $\mathrm{C} 2 \mathrm{C}$.

\section{Recommendations}

Based upon both the literature reviewed and the field study findings, the following recommendations could be suggested to the marketing managers in Resorts:

1. Necessity to focus on the registration of the website addresses to the resorts on international and Arab search engines, 
leading to further spread of these sites on the internet and easily accessible by guests all over the world.

2. The resort management must provide all the information and news that benefit the customers, as well as all the information related to the policies of booking on their websites as well as social networking pages of these resorts and updated them permanently and continuously to attract more customers.

3. The interest in publishing important information about the Arab Republic of Egypt on the websites and social networking pages of resorts such as (geographical location weather - currency used ... and so on).

4. Providing offers for guests on websites include discounts in the prices of services and recreational activities offered by the resorts, especially at times when demand for these services is reduced and advertised using attractive advertisements.

5. The need to provide security and privacy elements to encourage guests to book through the site quickly and easily.

6. The diversity of different foreign languages within the websites of the resorts so that not only the use of English as in most websites, but the content of these sites must be presented in several other languages such as (French-German-RussianItalian-Spanish).

\footnotetext{
${ }^{1}$ Master Researcher Faculty of Tourism and Hotels - Mansoura University

${ }^{2}$ Ass. Prof of Hotel management- Faculty of Tourism and Hotels - Mansoura University

${ }^{3}$ Prof of Accounting Department - Faculty of Commerce - Mansoura University
} 


\section{References}

1. Baruca P. (2012). How do guests choose a hotel? University of Primorska, Faculty of Tourism Studies. Slovenia petra.

2. Bernoff, J. (2009). Advertising will change forever. Retrieved from http://adage.com/article/digitalnext/advertising-changeforever/138023/

3. Chaffey, D., Ellis-Chadwick, F., Johnston, K., and Mayer, R. (2006). "Internet Marketing: Strategy, Implementation and Practice". (3rd edition Ed.),Essex, England: Prentice Hall.

4. Chaffey, Dave \& Smith, Paul Russel.(2008). "E-Marketing Excellence: planning and optimizing your digital marketing". Third edition. Amsterdam: Elsevier.

5. Chaves, M. S., Gomes, R., and Pedron, C. (2012). Decisionmaking based on Online Reviews: The Small and Medium Hotel Management, in: 20European Conference on Information Systems, June 10-13, Barcelona, Spain.

6. Corley. J., Ken II., Jourdan, Z., and Ingram, W. Rhea. (2013). Internet marketing: a content analysis of the research. Electron Markets.

7. Loncaric. D., Radetic. N. (2015)."The implementation of emarketing in the hotel industry... Zbornik ... Dina Lončarić1 Nensi Radetić2".

8. Duffy, L., Dennis. (2005). "Affiliate marketing and its impact on e-commerce". Journal of Consumer Marketing, Vol. 22.Iss. 3.

9. Enz, C. (2008). "Creating a Competitive Advantage by Building Resource Capability: The case of outback steakhouse Korea", Cornell Hotel and Restaurant Administration Quarterly, Vol.49.Iss.1.

10.Frehse,J.(2008). "Innovative Product Development in Hotel Operations", Journal of Quality Assurance in Hospitality and Tourism. 
11.Goldsmith. E., Litvina W., Pana B. (2008). "Electronic wordof-mouth in hospitality and tourism management - Tourism management".

12.Goyette, I., Ricard, L., Bergeron, J., and Marticotte, F. (2010). "E-WOMScale: Word-of-Mouth Measurement Scale for eServices Context, Canadian Journal of Administrative Sciences".

13.Hoy, M., and Milne, G. (2010). "Gender differences in privacy-related measures for young adult Facebook users". Journal of Interactive Advertising.

14.Kim, B., and Oh, H. (2004). "How do hotel firms obtain a competitive advantage?", International Journal of Contemporary Hospitality Management, Vol.16. Iss.1.

15. Kotler.P., and Armstrong. G. (2005). "Principles of marketing". Tenth edition. United States. Pearson education Inc.

16.Kotler, P., and Keller, K. (2009). Marketing Management (13th Edition ed.): Pearson.

17.Lim, W. (2010)." The effects of social media networks in the hospitality industry", Master Thesis, William F. Harrah College of Hotel Administration, University of Nevada, Las Vegas.

18. Mickey, B. (2011). "Social media and marketing a major topic of discussion. Fun world.

19.Ryan, Damian and Jones, Calvin.(2012). "Digital Marketing. Marketing strategies for engaging the digital generation. UK: Kogan Page Limited.

20.Simon Hudson. (2008). Tourism and hospitality marketing: a global perspective.

21.Straus, J., Frost, R. (2001)." Electronic marketing, NJ: Prentice Hall. 
22. Tariq, M., and Wahid, F. (2011). "Assessing effectiveness of social media and traditional marketing approaches in terms of cost and target segment coverage". Interdisciplinary Journal of Contemporary Research in Business.

23.Vollmer, C., and Precourt, G. (2008). "Advertising, marketing, and media in an era of consumer control. New York, NY: McGraw-Hill.

24.World Tourism Institution, European Travel Commission (2008). "Handbook on E-marketing for Tourism Destinations, World Tourism Institution, Madrid.

25.Wright, E., Khanfar, N., Harrington, C., and Kizer, L. (2010). "The lasting effects of social media trends on advertising. Journal of Business and Economics Research.

26.Yannopoulos P. (2011). "Impact of the Internet on Marketing Strategy Formulation". International Journal of Business and Social Science.

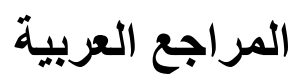

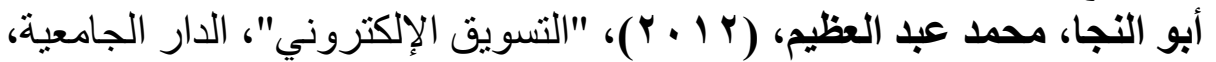

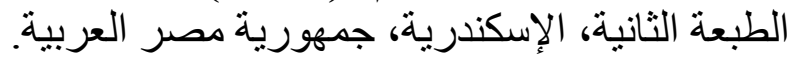

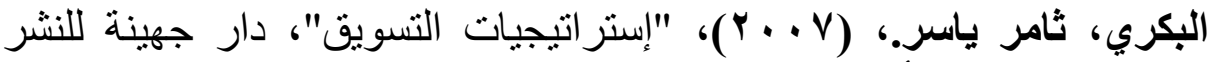

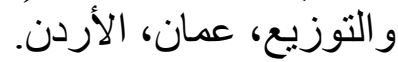

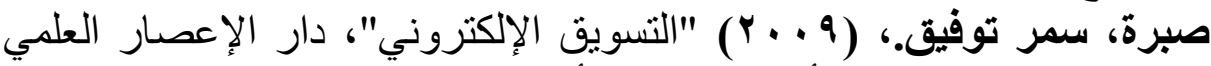

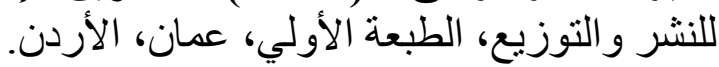

http://www.managementforum.org.sa/ar/Default.asp?Do= 4\& LinkToDisplay $=52$

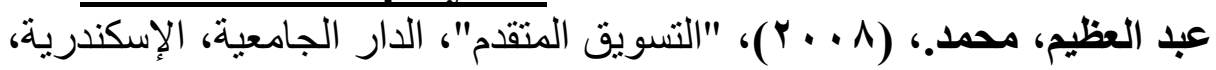
جمهورية مصر العربية. 